\title{
Characterization of ESBL (SHV-12) producing clinical isolate of Enterobacter aerogenes from a tertiary care hospital in Nigeria
}

\author{
Murat Kasap ${ }^{1 *}$, Kayode Fashae ${ }^{2}$, Sinem Torol ${ }^{1}$, Fetiye Kolayli ${ }^{3}$, Fatma Budak ${ }^{3}$, Haluk Vahaboglu ${ }^{4}$
}

\begin{abstract}
Background: We studied the beta-lactamases of an E. aerogenes isolate recovered from the blood of a two-yearold patient. The isolate demonstrated a disk-diffusion phenotype typical for an AmpC-ESBL co-producer.

Methods: Microbiology studies were performed according to standard protocols. The resistance gene was identified by transconjugation and cloning experiments.

Results: By transconjugation only a narrow spectrum beta-lactamase (TEM-1) encoded on a small plasmid was transmitted. The ESBL was cloned and expressed in an E. coli host. Sequence analysis of the recombinant plasmid revealed bla $a_{\mathrm{SHV}-12}$ associated to the insertion sequence, IS26.

Conclusion: This is the first study demonstrated the occurrence of SHV-12 in Nigeria.
\end{abstract}

\section{Background}

Enterobacter species, in particular, E. cloacae and $E$. aerogenes are able to compromise antibacterial treatment by over expressing the chromosomal AmpC betalactamase [1,2]. Emergence and spread of Class A extended-spectrum beta-lactamases (ESBLs) among these species are further complications [3].

ESBLs confer resistance to expanded-spectrum betalactam antibiotics. The majority of these enzymes are derived by amino acid substitutions from the narrow spectrum precursors, TEM-1, 2 and SHV-1. TEM-type ESBLs generally disseminate on transposons, Tn1, Tn2 and Tn3 [4]. SHV-type ESBLs, on the other hand, are typically associated to IS26 and disseminate through IS26 dependent mobilization events from the K. pneumoniae chromosome [5,6]. Eventually, the extended-spectrum derivates of TEM and SHV enzymes are now ubiquitous.

We detected an ESBL producing E. aerogenes clinical isolate from Nigeria. Since, the data in the literature regarding the occurrence and the dissemination of ESBLs in Nigeria is limited $[7,8]$, we characterized the beta-lactamases of this isolate by microbiological and molecular means

\footnotetext{
* Correspondence: mkasap@vt.edu

${ }^{1}$ Tibbi Biyoloji AD, KOU Tip Fakultesi, Izmit, Turkey
}

\section{Methods}

The strain and the susceptibility tests

A strain of Enterobacter aerogenes was isolated and identified by standard methods from the blood of a twoyear-old male patient, admitted (8th November 1999) to a tertiary care hospital in a Southwestern city of Nigeria, with clinical diagnosis of febrile convulsion. The case note is, however, not available for the history and outcome of the patient. The strain was identified by API 20E (bioMérieux Marcy l'Etoile, France) according to the instructions provided by the manufacturer.

Disk diffusion test was performed on Mueller-Hinton agar (disks and agar media were from Oxoid, Basingstoke UK) for the phenotypic identification of ESBLs as described elsewhere [9]. Briefly, the cefotaxime (CTX; $30-\mu \mathrm{g})$ disk was placed $20 \mathrm{~mm}$ away from the amoxicillin $(20-\mu \mathrm{g})$-clavulanate $(10-\mu \mathrm{g})(\mathrm{AMC})$ disk, the ceftazidime (CAZ; 30- $\mu \mathrm{g}$ ) disk was placed at $30 \mathrm{~mm}$ distance, and the cefepime (FEP; $30-\mu \mathrm{g})$ disk was placed at 30 $\mathrm{mm}$ distance. For the phenotypic detection of the AmpC enzyme, a cefoxitin (FOX; 30- $\mu \mathrm{g}$ ) disk was placed on the agar, as well.

The MICs of key antibiotics were determined by the broth micro-dilution test using Mueller-Hinton Broth (Oxoid, Basingstoke UK) as recommended by CLSI. End-points were interpreted after $18 \mathrm{~h}$ of incubation at 
$37^{\circ}$ C. E. coli ATCC 25922 and E. coli DH10B were included as control strains. Powder forms of antibiotics were obtained from local companies: ampicillin (Mustafa Nevzat), piperacillin \& tazobactam (Wyeth), clavulanate (DEPA), cefepime (Bristol-Myers Squibb), cefotaxime (Toprak), ceftazidime (Glaxo-SmithKline), imipenem (Merck), meropenem (Astra-Zeneca), ciprofloxacin (Bayer), gentamicin (Bilim) and tobramycin (Nobel). The final concentration of clavulanate was $4 \mathrm{mg} \mathrm{L}^{-1}$.

\section{Plasmid studies}

Plasmids were isolated by the alkaline lysis or the Kado Liu methods [10], run on $0.8 \%$ agarose gels and visualized under UV light. Transconjugation and transformation experiments were performed with E. coli J53-2 $\left(\right.$ Rif $^{\mathrm{R}}$ ) and electro-competent E. coli DH10B strains as recipients, respectively $[11,12]$.

\section{DNA \& RNA isolation, PCR and RT-PCR}

DNA templates for PCR experiments were prepared by simply boiling a dense bacterial suspension in $\mathrm{ddH}_{2} \mathrm{O}$ and a $10 \mathrm{~min}$ of centrifugation at $16.000 \times \mathrm{g}$. DNA-free RNAs were isolated with RNeasy Mini Kit (Qiagen), and run on denaturating gel conditions to check the integrity of RNAs and the lack of visible DNA contamination. cDNAs were immediately synthesized by random hexamer primers with Revert Aid first strand cDNA synthesis kit (Fermentas, Lithuania).

PCR reactions were set in $50 \mu$ final volumes made up of $1 \times$ buffer, $1.5 \mathrm{U}$ Taq polymerase (Fermentas, Lithuania), $1.5 \mathrm{mM} \mathrm{MgCl} 2,0.8 \mathrm{mM}$ dNTPs, 50 pmol primers each. RT-PCR was set up with the same master mixture except, 1× SYBR Green I (Sigma) was added. Reactions were prepared on ice and run on Quantica (Techne) RT-PCR Thermal cycler as described elsewhere [13]. Specificity of the product was assessed by the dissociation curve analysis made by the Quantica software and the relative mobility of the PCR products on the agarose gels.

Primers, ShvF1-5'-ATTACCATgAgCgATAACAg-3' and ShvR1-5'-CATTCAgTTCCgTTTCCC-3' were used $\left(55^{\circ} \mathrm{C}\right.$ annealing temperature) in RealTime-PCR to amplify a $133 \mathrm{bp}$ fragment internal to $b l a_{\mathrm{SHV}-12}$ gene. The primer ShvF1 and the primer DeoRR1-5'CCAggTggTCACCAATgATT-3' were used $\left(50^{\circ} \mathrm{C}\right.$ annealing temperature) to amplify a 927 bp fragment which extends from the 3 ' end of the $b l a_{\mathrm{SHV}-12}$ gene to the $402 \mathrm{bp}$ of the transcriptional regulator gene. To amplify the entire sequence $(861 \mathrm{bp})$ of bla the primers TemA-5'-ATgAgTATTCAACAT TTCCgTg-3' and TEMD-5'-TTACCAATgCTTAATCAgTgAg-3' (annealing temp. $52^{\circ} \mathrm{C}$ ) were used.

IEF

Crude cell extracts were prepared by sonication. Analytical isoelectric focusing (IEF) was performed on a $5 \%$ polyacrylamide gel containing ampholytes ( $\mathrm{pH}$ range, 3-
10; Bio-Rad Laboratories, USA) with a Model 111 Mini IEF Cell (Bio-Rad). SHV-1 (pI 7.6), OXA-14 (pI 6.2) and TEM-1 (pI 5.4) were included as references. Enzymes were focused at a constant $1 \mathrm{~W}$ for $45 \mathrm{~min}$ and detected by overlaying the gel with $1 \mathrm{mM}$ nitrocefin solution.

\section{Cloning and sequencing}

High molecular weight (HMW) genomic DNA was isolated using the procedure described by Chen and Kuo [14]. For plasmid DNA isolation, alkaline lysis method was used (Sambrook and Russell, 2001). Twenty micrograms each of HMW genomic DNA and plasmid DNA were digested with 0.1 units of Bsp143I (Fermentas) for $20 \mathrm{~min}$ at $37^{\circ} \mathrm{C}$ and 0.5 microgram of the cloning vector, pZero (Invitrogen), was digested with 5 units of $\mathrm{BamHI}$ (Fermentas) for one hour at $37^{\circ} \mathrm{C}$. Digested DNA and the vector were phenol/chloroform extracted and compatible arms were ligated overnight at $16^{\circ} \mathrm{C}$. Two microliters of ligation mix was then transformed to electrocompetent $E$. coli $\mathrm{DH} 10 \mathrm{~B}$ and the recombinant clones were selected on agar plates supplemented with ampicillin $(100 \mathrm{mcg} / \mathrm{mL})$ plus zeocin $(50 \mathrm{mcg} / \mathrm{mL})$.

Dye terminator cycle sequencing with the ABI Prism BigDye Terminator kit (Applied Biosystems, Foster City, Calif.) were used to obtain the sequences. The assay was carried out according to the standardprotocol. Data was collected on an ABI 377 automated fluorescence sequencer.

\section{Results}

The isolate, identified as E. aerogenes (EaN146), exhibited a phenotype by the disk diffusion test that is typical for an AmpC-ESBL co-producer [9]. Briefly, there was no zone around the FOX disk which was specifically caused by the over-expressed AmpC enzyme whereas the zone around the FEB disk was enlarged on the AMC side, indicating the existence of a Class A ESBL.

By transformation we were able to transfer a narrow spectrum enzyme encoded on a $<7 \mathrm{~kb}$ cryptic plasmid (data not shown) to DH10B recipient (TN146) which was identified as TEM-1 by sequencing on both sides of the PCR product.

By shotgun cloning, on the other hand, we recovered a positive clone (CN146) possessing an ESBL. Sequencing of the recombinant plasmid ( $\mathrm{pCEaN146)}$ from this clone revealed a 5656-bp insert (Figure 1; GenBank accession \# EU534207) on which we determined an open reading frame (ORF) encoding the ESBL, SHV-12 and an insertion sequence, IS26, upstream (73-bp) of the bla gene with perfect $14 \mathrm{bp}$ terminal inverted repeats [15]. With the aid of ORF finding software (MB DNA Analysis v6.84) and Blast comparison against the sequences submitted to GenBank we identified three more intact ORFs and one another ORF disrupted by IS26. Interestingly, we detected a 9-bp direct repeat sequence 


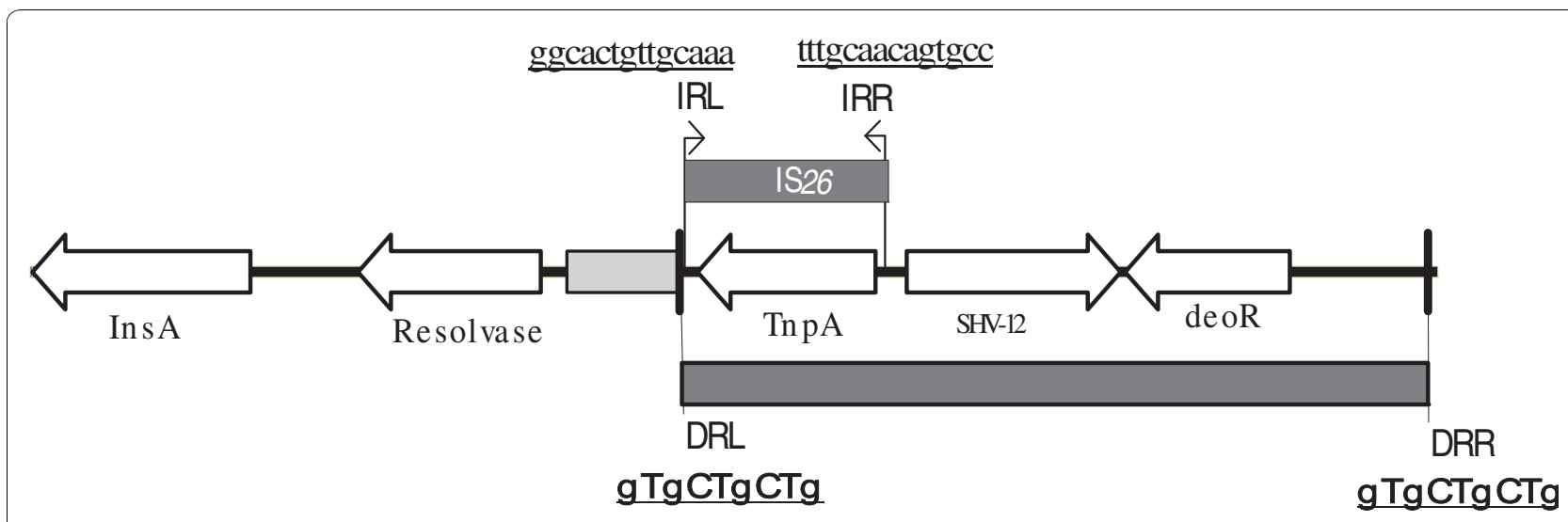

\section{6 bp}

Figure 1 The schematic map of the cloned insert (5656 bp). ORFs are indicated by empty arrows and repeat regions by dark shaded boxes.

(GTGCTGCTG) flanking on the left and right boundaries of a 3002-bp which might be an incomplete transposable unit.

MICs of the strains are shown in Table 1. E. aerogenes is highly resistant to beta-lactam antibiotics except carbapenems. In this strain clavulanate apparently potentiated the activity of cefepime which is relatively stable against the AmpC type enzyme and hydrolyzed only by the ESBL, but not enhanced the activity of ceftazidime which is hydrolyzed by the clavulanate resistant AmpC enzyme [9].

The IEF experiment is presented in Figure 2. Only two enzymes (pI $5.4 \& \mathrm{pI} 9$ ) were visible in the lane of $E$.

Table 1 The MICs of key antibiotics for SHV-12 producing E. aerogenes (EaN146), the transformant (TFN146) and the SHV-12 producing clone (CN146)

\begin{tabular}{lrrr}
\hline $\mathbf{A b}^{\mathbf{a}}$ & \multicolumn{3}{c}{$\boldsymbol{\mu \mathbf { g } / \mathbf { m l }}$} \\
\hline & $\geq 256 \mathbf{N 1 4 6}$ & TFN146 & $\mathbf{C N 1 4 6}$ \\
\hline Ampicillin & $\geq 256$ & $\geq 256$ & $\geq 256$ \\
Ampicillin/Clav & 16 & 64 & 32 \\
Cefepime & 0,025 & 0,5 & 128 \\
Cefepime/Clav & 128 & 0,025 & 0,025 \\
Ceftazidime & 64 & 0,5 & $\geq 256$ \\
Ceftazidime/Clav & 16 & 0,5 & 4 \\
Cefotaxime & 32 & $<1$ & $>256$ \\
Piperacillin & $<4$ & $>128$ & $>128$ \\
Piperacillin/Tazo & $<1$ & $<4$ & $>128$ \\
Imipenem & $<0.25$ & $<1$ & $<1$ \\
Meropenem & $<0.25$ & $<0.25$ & $<0.25$ \\
Ciprofloxacin & $>16$ & $<0.25$ & $<0.25$ \\
Gentamicin & 8 & $<1$ & $<1$ \\
Tobramycin & $<1$ & $<1$ \\
\hline Clav, Clavulanate & & $<1$ &
\end{tabular}

${ }^{\mathrm{a} C l a v}$, clavulanate $(4 \mu \mathrm{g} / \mathrm{ml})$, Tazo, tazobactam $(8 \mu \mathrm{g} / \mathrm{ml})$ aerogenes, one representing the $\mathrm{AmpC}(\mathrm{pI} 9)$ and the other representing the TEM-1 (pI 5.4). At pI 8.2, after several minutes of incubation a faint band, possibly corresponding to SHV12, appeared while the other bands diffused preventing us to record a good image (data not shown). To confirm the expression of SHV-12 in EaN146, we performed a RT-PCR experiment with primers ShvF1 and ShvR1. Template DNAs were transcribed from the mRNAs of EaN146, CN146 and TN146. This experiment demonstrated that, although low in amount, EaN146 is expressing SHV-12.

\section{Discussion}

This study characterized the beta-lactamases from a clinical isolate of $E$. aerogenes and demonstrated the occurrence of IS26 associated bla $a_{\mathrm{SHV}-12}$ in Nigeria. SHV-12 was first identified in 1997 in Switzerland and later reported from various continents including Africa [16-20]. Reports of SHV-12 producing E. cloacae and Klebsiella blood isolates from Tanzania and Cameroon and now $E$. aerogenes from Nigeria indicate a high endemicity of SHV-12 possessing Enterobacteriaceae in the Western coast of Africa and therefore attract interest.

SHV-1 is supposed to be a species specific enzyme encoded mainly on the chromosome of $K$. pneumoniae $[5,21]$. Evolutionary analysis of submitted sequences indicated that extended-spectrum variants evolved on two branches from bla $a_{\mathrm{SHV}-1}$, both mediated by IS 26 depended mobilization events from the chromosome of K. pneumoniae [6]. These analyses revealed that $b l a_{\mathrm{SHV}}$ ${ }_{12}$ evolved from the branch of bla $a_{\mathrm{SHV}-2 \mathrm{a}}$. Indeed, the genes surrounding $b l a_{\mathrm{SHV}-12}$ in this study is identical to the genes surrounding bla $a_{\mathrm{SHV}-2 \mathrm{a}}$ in several previously submitted sequences (GenBank accession \#s: X84314 and X53817). This suggests that bla $a_{\mathrm{SHV}-12}$ identified in 


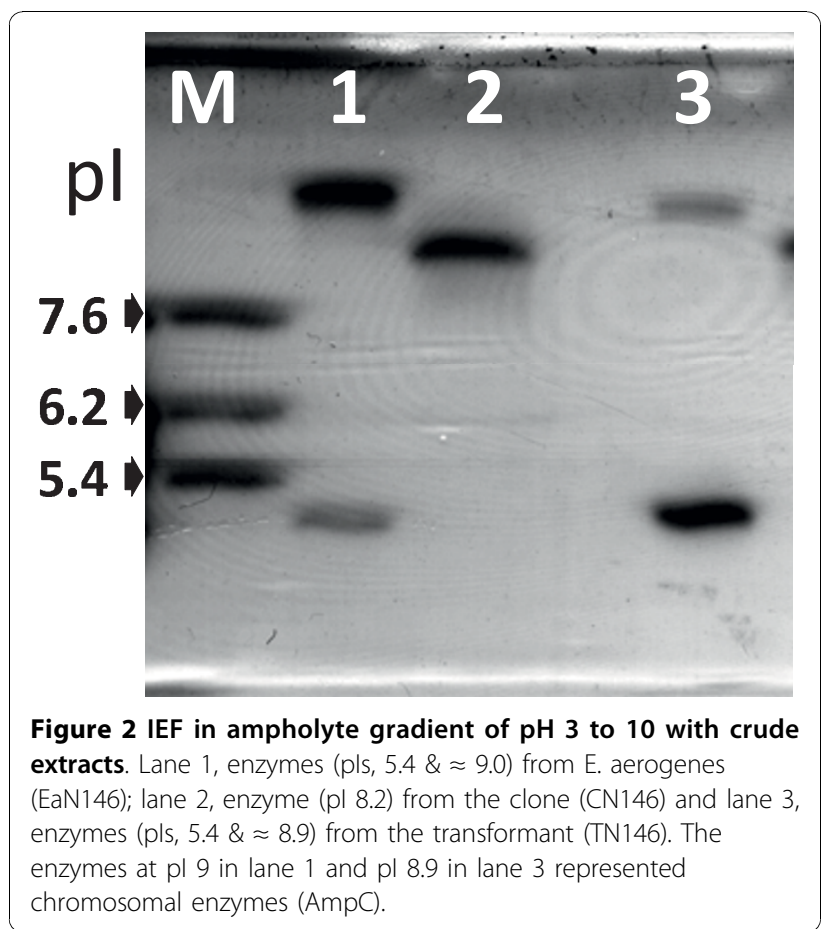

this study has evolved from $b l a_{\mathrm{SHV}-2 \mathrm{a}}$ as supposed by the evolutionary approach [6].

IS26 is an 820-bp long insertion sequence that typically generates 8 bp target duplication upon transposition [15]. It is demonstrated for IS1 that the length of target site duplication sequences may vary according to the sequence of the integrated site [22]. This phenomenon has not been studied for IS26. In this study we identified a 9 bp direct repeat on the boundaries of a 3002 bp region bearing $b l a_{\mathrm{SHV}-12}$ and the DeoR type regulator gene. This $3002 \mathrm{bp}$ region may be a replicating unit.

Data for ESBLs from Nigeria are rare in the literature $[7,8,23]$. In a study by Soge et al., CTX-M-15 producing K. pneumoniae clinical isolates were characterized [7]. In another study, the authors characterized ESBLs by phenotypic means among E. aerogenes [8].

\section{Conclusions}

This is the first study reporting the occurrence and the genetic support of ESBL $b l a_{\mathrm{SHV}-12}$ gene in Nigeria.

\section{Acknowledgements}

This study was supported by the Research Fund of Kocaeli University under the grant number of 2007/079.

\section{Author details}

${ }^{1}$ Tibbi Biyoloji AD, KOU Tip Fakultesi, Izmit, Turkey. ${ }^{2}$ Department of Botany and Microbiology University of Ibadan, Nigeria. ${ }^{3}$ Mikrobiyoloji ve Klinik Mikrobiyoloji AD, KOU Tip Fakultesi, Izmit, Turkey. ${ }^{4}$ Enfeksiyon Hastaliklari ve Klinik Mikrobiyoloji AD, KOU Tip Fakultesi, Izmit, Turkey.

\section{Authors' contributions}

The microbiology work including the resistance tests and tansconjugation was performed by KF, FK and FB. Molecular biology work including cloning and sequence analysis of the clone was performed by MK and ST. The study design, preparation of the manuscript and all aspects of intellectua contributions were by MK and HV. All authors read and approved the final manuscript.

\section{Competing interests}

The authors declare that they have no competing interests.

Received: 14 November 2009

Accepted: 12 January 2010 Published: 12 January 2010

\section{References}

1. Chow JW, Fine MJ, Shlaes DM, Quinn JP, Hooper DC, Johnson MP, Ramphal R, Wagener MM, Miyashiro DK, Yu VL: Enterobacter bacteremia: clinical features and emergence of antibiotic resistance during therapy. Annals of internal medicine 1991, 115:585-590.

2. Pfaller MA, Jones RN, Marshall SA, Coffman SL, Hollis RJ, Edmond MB, Wenzel RP: Inducible amp C beta-lactamase producing gram-negative bacilli from blood stream infections: frequency, antimicrobial susceptibility, and molecular epidemiology in a national surveillance program (SCOPE). Diagn Microbiol Infect Dis 1997, 28:211-219.

3. Tzelepi E, Giakkoupi P, Sofianou D, Loukova V, Kemeroglou A, Tsakris A: Detection of extended-spectrum beta-lactamases in clinical isolates of Enterobacter cloacae and Enterobacter aerogenes. J Clin Microbiol 2000, 38:542-546.

4. Partridge SR, Hall RM: Evolution of transposons containing blaTEM genes. Antimicrob Agents Chemother 2005, 49:1267-1268.

5. Chaves J, Ladona MG, Segura C, Coira A, Reig R, Ampurdanes C: SHV-1 beta-lactamase is mainly a chromosomally encoded species-specific enzyme in Klebsiella pneumoniae. Antimicrob Agents Chemother 2001, 45:2856-2861.

6. Ford PJ, Avison MB: Evolutionary mapping of the SHV beta-lactamase and evidence for two separate IS26-dependent blaSHV mobilization events from the Klebsiella pneumoniae chromosome. J Antimicrob Chemother 2004, 54:69-75.

7. Soge OO, Queenan AM, Ojo KK, Adeniyi BA, Roberts MC: CTX-M-15 extended-spectrum (beta)-lactamase from Nigerian Klebsiella pneumoniae. J Antimicrob Chemother 2006, 57:24-30.

8. Aibinu IE, Ohaegbulam VC, Adenipekun EA, Ogunsola FT, Odugbemi TO, Mee BJ: Extended-spectrum beta-lactamase enzymes in clinical isolates of Enterobacter species from Lagos, Nigeria. J Clin Microbiol 2003, 41:2197-2200.

9. Pitout JD, Reisbig MD, Venter EC, Church DL, Hanson ND: Modification of the double-disk test for detection of enterobacteriaceae producing extended-spectrum and AmpC beta-lactamases. J Clin Microbiol 2003, 41:3933-3935.

10. Kado Cl, Liu ST: Rapid procedure for detection and isolation of large and small plasmids. Journal of bacteriology 1981, 145:1365-1373.

11. Vahaboglu H, Budak F, Kasap M, Gacar G, Torol S, Karadenizli A, Kolayli F, Eroglu C: High prevalence of OXA-51-type class D beta-lactamases among ceftazidime-resistant clinical isolates of Acinetobacter spp.: coexistence with OXA-58 in multiple centres. J Antimicrob Chemother 2006, 58:537-542.

12. Akhan $\mathrm{S}$, Coskunkan $\mathrm{F}$, Tansel $\mathrm{O}$, Vahaboglu $\mathrm{H}$ : Conjugative resistance to tazobactam plus piperacillin among extended-spectrum beta-lactamaseproducing nosocomial Klebsiella pneumoniae. Scand J Infect Dis 2001, 33:512-515.

13. Savli H, Karadenizli A, Kolayli F, Gundes S, Ozbek U, Vahaboglu H: Expression stability of six housekeeping genes: A proposal for resistance gene quantification studies of Pseudomonas aeruginosa by real-time quantitative RT-PCR. J Med Microbiol 2003, 52:403-408.

14. Chen WP, Kuo TT: A simple and rapid method for the preparation of gram-negative bacterial genomic DNA. Nucleic Acids Res 1993, 21:2260.

15. Mollet B, lida S, Shepherd J, Arber W: Nucleotide sequence of IS26, a new prokaryotic mobile genetic element. Nucleic Acids Res 1983, 11:6319-6330.

16. Nuesch-Inderbinen MT, Kayser FH, Hachler H: Survey and molecular genetics of SHV beta-lactamases in Enterobacteriaceae in Switzerland: 
two novel enzymes, SHV-11 and SHV-12. Antimicrob Agents Chemother 1997, 41:943-949.

17. Gray KJ, Wilson LK, Phiri A, Corkill JE, French N, Hart CA: Identification and characterization of ceftriaxone resistance and extended-spectrum betalactamases in Malawian bacteraemic Enterobacteriaceae. J Antimicrob Chemother 2006, 57:661-665.

18. Gangoue-Pieboji J, Bedenic B, Koulla-Shiro S, Randegger C, Adiogo D, Ngassam P, Ndumbe P, Hachler H: Extended-spectrum-beta-lactamaseproducing Enterobacteriaceae in Yaounde, Cameroon. J Clin Microbiol 2005, 43:3273-3277.

19. Blomberg B, Jureen R, Manji KP, Tamim BS, Mwakagile DS, Urassa WK, Fataki M, Msangi V, Tellevik MG, Maselle SY, Langeland N: High rate of fatal cases of pediatric septicemia caused by gram-negative bacteria with extended-spectrum beta-lactamases in Dar es Salaam, Tanzania. J Clin Microbiol 2005, 43:745-749.

20. Ben-Hamouda T, Foulon T, Ben-Mahrez K: Involvement of SHV-12 and SHV-2a encoding plasmids in outbreaks of extended-spectrum betalactamase-producing Klebsiella pneumoniae in a Tunisian neonatal ward. Microbial drug resistance (Larchmont, NY) 2004, 10:132-138.

21. Babini GS, Livermore DM: Are SHV beta-lactamases universal in Klebsiella pneumoniae?. Antimicrob Agents Chemother 2000, 44:2230.

22. Machida C, Machida Y: Base substitutions in transposable element ISI cause DNA duplication of variable length at the target site for plasmid co-integration. EMBO J 1987, 6:1799-1803.

23. Iregbu KC, Elegba OY, Babaniyi IB: Bacteriological profile of neonatal septicaemia in a tertiary hospital in Nigeria. African health sciences 2006, 6:151-154.

doi:10.1186/1476-0711-9-1

Cite this article as: Kasap et al:: Characterization of ESBL (SHV-12)

producing clinical isolate of Enterobacter aerogenes from a tertiary care hospital in Nigeria. Annals of Clinical Microbiology and Antimicrobials 2010 9:1.

Publish with Biomed Central and every scientist can read your work free of charge

"BioMed Central will be the most significant development for disseminating the results of biomedical research in our lifetime. "

Sir Paul Nurse, Cancer Research UK

Your research papers will be:

- available free of charge to the entire biomedical community

- peer reviewed and published immediately upon acceptance

- cited in PubMed and archived on PubMed Central

- yours - you keep the copyright 